\title{
Reduction a Particulate Matter of Diesel Emission by the Use of Several Oxygenated Diesel Blend Fuels
}

\author{
Ali Alahmer* \\ Department of Mechanical Engineering, Tafila Technical University, Tafila, Jordan, P. O. Box 179, 66110
}

\begin{abstract}
Oxygenated diesel fuel blends have a prospective effectiveness to reduce a particulate matter (PM) emissions and powerfully to be an effective alternative instead of diesel fuel. This manuscript investigates the emission characteristics of four combinations of oxygenated diesel fuel blends in terms of ethanol, TGME, Glyme and Diglyme. Two blended fuels containing $5 \%$ and $15 \%$ by volume for each oxygenated additives was prepared. Pure diesel fuel was used as a base fuel for all oxygenated diesel blends. The experiments were conducted using four cylinders, four stroke compression ignition Toyota Hilux Pickup of engine capacity (2494 cc) model 2006, inline DOHC 16 Valve. The experimental results showed that (i) the higher engine speed is produced lower PM emissions; (ii) the PM emitted by all the oxygenated diesel blends is significantly lower than of the corresponding pure diesel fuel; (iii) the increase of oxygenated percentage in the diesel blends, the PM emission decreases; (iv) A maximum and minimum of PM reduction was occurred when the engine fueled by $15 \%$ by volume for ethanol and by $5 \%$ by volume for TGME respectively.
\end{abstract}

Keywords: Diesel, emission, oxygenated additive, particulate matter, ethanol, Glyme, Diglyme

\section{Introduction}

Diesel engines have been widely used in industrial applications, transportation due to their better drivability, fuel efficiency, rigid structure, less waste heat while in operation, reliability, easily accept synthetic fuels without significantly manufactured modification, high performance and power capacity [1]. However, it is considered as the major source of air polluting exhaust gases such as particulate matter (PM), carbon monoxide (CO), oxides of nitrogen (NOx) and other harmful compounds. Increasing the demand for cleaner burning diesel fuels is growing worldwide, as governmental regulations make emission reduction necessary. Table 1 shows the European emission standards for diesel passenger cars [2]. The reduction of emissions from engines has become a major factor in the development of new engines and manufacturers in order to meet the international emissions standards. To achieve significant reductions in emissions, it must be improved diesel fuel by increasing the cetane number, reducing the sulfur content, lowering the aromatic content, increasing fuel volatility and decreasing the fuel density, increase of oxygen concentration within the fuel to have the compromise between engine performance and engine out emissions [3]. Oxygenates are well known to reduce particulate emissions through improve combustion efficiency, increase cetane number, and reduce fuel deposits the formation as particulate matter which consists about $60-80 \%$ of the emission of diesel fuel combustion [4]. Recent studies have shown that the improvement in exhaust emissions provided by oxygenate fuels is strongly depended on the oxygen concentration in the fuels, because these compounds inhibit soot formation during the combustion process, and thus greatly reduce emissions of visible smoke $[5,6]$.

Several researchers have studied the effect of adding oxygenate additives to diesel fuel on the engine performance and emission. Patil and Taji [4] investigate the effect of different oxygenated additives on the exhaust gas emission. They found that oxygenated are the effective method for reducing PM, CO and $\mathrm{HC}$ without significant increase in the NOx emission. Mccormick et al. [7] blend several oxygenate additives in terms of ethanol, octanol, decanoic acid and methyl soy ester at weight $1 \%$ and $2 \%$ of oxygen level with diesel fuel. The emissions were measured by the hot start portion of the U.S. The results showed the PM reductions by $10-15 \%$ were occurred regardless of oxygenate chemical structure. The emission characteristics of the methyl soyate and ethanol blended with diesel fuel in ratio $15 \%$ and $20 \%$ by volume was

\footnotetext{
${ }^{*}$ Corresponding author. Tel.: +962-798277537

E-mail: A.alahmer@ttu.edu.jo

(C) 2014 International Association for Sharing Knowledge and Sustainability

DOI: $10.5383 /$ ijtee.07.01.006
} 
analyzed by Shi et al. [8] His observations showed that PM emission decreased with increasing oxygenate content in the fuels but the nitrogen oxides (NOx) emissions was increased. Schaus et al. [9] mixed ethanol in ratio 10 and $15 \%$ by volume within diesel fuel. The measurements proofed a vary reduction of PM and an increase of NOx emissions depends basically on the speed and load of the engine. He et al. [10] examined the effect of ethanol blended diesel fuels on emissions from a diesel engine. The results showed the addition of ethanol to diesel fuel changes the physicochemical properties of the blends. As increase of ethanol concentration, the diesel properties in terms of density, cetane number, kinematic viscosity, high heat value and aromatics fractions of the blends decrease. Also as increase of ethanol, the emission in form of smoke, NOx and $\mathrm{CO} 2$ decrease and $\mathrm{CO}$, acetaldehyde emissions and un-burn ethanol emissions increase at most operating conditions.

Baskar et al. [11] investigated the influence of two different synthetic oxygenated additives namely Diphenyl ether (DPE) and Diethelene glycol dimethyl ether (DIGLYME) blended in ratio $10 \%-15 \%$ by volume with diesel fuels on the exhaust emissions The results showed, there is significant reduction of engine emissions of hydrocarbon and carbon monoxide emissions while the coefficient of light absorption of smoke opacimeter decreases by about $50 \%$ for DPE10, DIGLYME10 blend and it was reduced by about 60\% for DPE15 and DIGLYME15 blend .

Lin and Huang [12] investigated the effects of using ethylene glycol monoacetate as an oxygenating additive for diesel oil on the performance and emission characteristics of marine diesel engines under varying air temperature and humidity. The Ethylene glycol monoacetate addition into the diesel fuel caused an increase in brake specific fuel consumption (BSFC), with lowered exhaust gas temperature, $\mathrm{NOx}, \mathrm{CO}$ and $\mathrm{CO} 2$ emissions. The effect of three oxygenated additives (methane, ethane and acetone) on the formation of soot emitted during the combustion of diesel was investigated by Burshaid and Hamdan [13]. The result showed the methanol additive has the most significant effect on the reduction of soot, while acetone has the lease effect on soot reduction. Hasib and Rahman [14] examined different blends of mustard oil biodiesel on the performance and emission polluted from small four stroke diesel engine. The result showed the use of biodiesel has certain advantages over pure diesel fuel. It emits cleaner emission (except for NOx), reduces global warming and enhances rural development.

After surveying the published papers, the important variables that effected on PM emissions can be summarized in table 2 .

Table 1. EU emissions standards for passenger cars (in $\mathrm{g} / \mathrm{km}$ ).

\begin{tabular}{|c|c|c|c|c|c|c|}
\hline & $\underset{\text { I }}{\text { EURO }}$ & $\begin{array}{c}\text { EURO } \\
\text { II }\end{array}$ & $\begin{array}{c}\text { EURO } \\
\text { III }\end{array}$ & $\begin{array}{c}\text { EURO } \\
\text { IV }\end{array}$ & $\underset{\mathbf{V}}{\text { EURO }}$ & $\begin{array}{c}\text { EURO } \\
\text { VI }\end{array}$ \\
\hline Year & 1993 & 1997 & 2001 & 2006 & 2010 & 2015 \\
\hline NO $_{x}$ & - & - & 0.5 & 0.25 & 0.18 & 0.08 \\
\hline PM & 0.14 & 0.08 & 0.05 & 0.025 & 0.005 & 0.005 \\
\hline $\mathrm{CO}$ & 2.72 & 1 & 0.64 & 0.5 & 0.5 & 0.5 \\
\hline
\end{tabular}

Table 2. Summarize of the variables that effected on PM emissions.

\begin{tabular}{|c|c|}
\hline \multicolumn{2}{|r|}{ PM Emission Factors } \\
\hline Criterion & Parameters \\
\hline fuel composition & $\begin{array}{l}\text { oxygen content, oxygenate molecular } \\
\text { structure, aromatic content, amount of sulfur } \\
\text { content in diesel fuel }\end{array}$ \\
\hline Engine operation & Load, speed, steady state and transient \\
\hline $\begin{array}{c}\text { Fuel injection system } \\
\text { performance }\end{array}$ & $\begin{array}{c}\text { injection pressure, orifice diameter, and } \\
\text { number of orifices }\end{array}$ \\
\hline Combustion phasing & $\begin{array}{c}\text { Start end and rate of chemical energy release } \\
\text { during combustion. }\end{array}$ \\
\hline $\begin{array}{l}\text { Intake air } \\
\text { composition and } \\
\text { temperature }\end{array}$ & $\begin{array}{l}\text { Exhaust gas recirculation (EGR) or turbo- } \\
\text { charging }\end{array}$ \\
\hline $\begin{array}{l}\text { In-cylinder flow } \\
\text { fields }\end{array}$ & $\begin{array}{c}\text { combustion chamber geometry, turbulence } \\
\text { intensity }\end{array}$ \\
\hline
\end{tabular}

The aims of this manuscript is to reduce PM from the combustion of high sulfur diesel fuel using several oxygenated additives. The structure of this manuscript starts by discussing the related research from the body of literature in section one, while the section two presents oxygenate criterion selection. Section three experimental approach and setup were displayed. The section four presents the results and the discussion; while section five summarizes the study findings through the conclusion

\section{Oxygenate Criterion Selection}

The crucial parameters to select the most suitable oxygen additives can be summarized by: cost, toxicity, environmental impact, fuel blending properties in terms the amount of oxygen in the fuel, fuel solubility, minimal impact on cetane number, boiling point, flash point, self-ignition temperature, and finally effect on the engine performance. The oxygenated additive should be soluble in the diesel fuel over the range of environmental temperature in range 5 to $20 \%$ by volume to achieve maximum emissions reduction and improved engine performance. According to Standard Specification for Diesel Fuel Oils D-975 issued by American Society for Testing and Materials (ASTM) to reduce the transportation flammability risk, the oxygenated diesel fuel flashpoint and boiling point must be over $52^{\circ} \mathrm{C}, 60^{\circ} \mathrm{C}$ respectively; the self-ignition temperature and kinematic viscosity must be lower than $350^{\circ}$ C, $4 \mathrm{~mm} 2 / \mathrm{s}$ respectively $[4,15]$.

\section{Experimental Methodology}

This section presents a full detailed description of the experimental setup, apparatus and procedures were used.

\subsection{Diesel Blends Preparation}

A high sulfur content Jordanian diesel fuel was used in this experiment. Sulfur content in the Jordanian diesel fuel reaches to $1.2 \%$, while in the European standards this ratio reaches $0.35 \%$. The specification of diesel fuel was displayed in table 3 . The specification table was issued from the technical service department in the Jordanian Petroleum Refinery Company. Four types of synthetic oxygenated compound namely ethanol, 
tripropylene glycol methyl ether (TGME), ethylene glycol dimethyl ether (Glyme) and diethylene glycol dimethyl ether (Diglyme) were selected for this study. A physical and chemical properties of oxygenated additives were depicted in table 4 . Two blended fuels containing $5 \%$ and $15 \%$ by volume for each oxygenated additives was prepared. Pure diesel fuel was used as a base fuel for all oxygenated diesel blends. The preparation blend was exposed to air at least one month to check of stability before perform a test.

\subsection{Emission Measurements}

In the automotive industry, particulates emission generally can be measured in a dilution tunnel. The exhaust gases is sampled and diluted in a dilution tunnel with ambient air at temperature below $52^{\circ} \mathrm{C}$ [7]. The mass of the particulate matter is determined by filtering the gases through a Teflon coated fiberglass filter, regardless of size distribution. When the trapped particulate is treated with a solvent, the soluble fraction can be separated from the soot and it is called dry soot. The soluble fraction typically accounts for $15-45 \%$ of the particulate mass [16]. When particulate is sampled, two independent mass flow controllers are used: (i) the total filtered gas sample and (ii) the air rate. The computers emission software determines the total sample volume by integrating the instantaneous flow difference. Flow is made proportional by sending a varying air flow set point from the test manager computer, which is based upon the critical flow venture (CFV) rate. The exhaust emission of particulate matter was measured using Bosh emission analysis as shown in figure 1 .

Table 3. Jordanian Diesel Fuel Specifications

\begin{tabular}{|c|c|c|}
\hline Test & Specification & Method \\
\hline $90 \%$ Recovered & Max. 357 & $\begin{array}{l}\text { ASTM D- } \\
1298\end{array}$ \\
\hline Density @ $15^{\circ} \mathrm{C}(\mathrm{g} / \mathrm{ml})$ & $0.820-0.870$ & $\begin{array}{l}\text { ASTM D- } \\
1500\end{array}$ \\
\hline Color & Max. 2.5 & $\begin{array}{l}\text { ASTM D- } \\
1266\end{array}$ \\
\hline Total Sulfur \% wt & Max. 1.2 & ASTM D-93 \\
\hline $\begin{array}{c}\text { Kinematic Viscosity Cst @ } \\
40^{\circ} \mathrm{C}\end{array}$ & Min. 50 & ASTM D-445 \\
\hline Pour Point ${ }^{\circ} \mathrm{C}$ & $\begin{array}{c}\text { Max. +5 (Summer); } \\
-9 \text { (Winter) }\end{array}$ & ASTM D-97 \\
\hline $\begin{array}{l}\text { Corrosion, Cooper, } \\
\text { Classification }\end{array}$ & 1 & ASTM D-130 \\
\hline $\begin{array}{l}\text { Carbon Residue on } 10 \% \\
\text { residue } \% \mathrm{wt}\end{array}$ & Max. 0.1 & ASTM D-189 \\
\hline $\begin{array}{l}\text { Total Acid Number (mg } \\
\text { KOH/mg) }\end{array}$ & Max. 1.0 & ASTM D-974 \\
\hline $\begin{array}{c}\text { Strong Acid Number (mg } \\
\mathrm{KOH} / \mathrm{mg})\end{array}$ & NIL & ASTM D-974 \\
\hline ASH \% wt & Max. 0.01 & ASTM D-482 \\
\hline Water by Distillation \% Vol & Max. 0.05 & ASTM D-95 \\
\hline Sediment by Extraction & Max. 0.01 & ASTM D-473 \\
\hline Diesel Index & Min. 50 & IP-21 \\
\hline Cetane Index & Min. 46 & $\begin{array}{l}\text { ASTM D- } \\
9760\end{array}$ \\
\hline & & or $\quad \mathrm{D}-4737$ \\
\hline
\end{tabular}

Table 4. Physical and chemical properties for Oxygenated Compounds

\begin{tabular}{|c|c|c|c|c|}
\hline & \multicolumn{4}{|c|}{ Oxygenated Compounds } \\
\cline { 2 - 5 } Benchmarks & Ethanol & $\begin{array}{c}\text { Tripropylene } \\
\text { Glycol } \\
\text { Methyl Ether } \\
\text { (TGME) }\end{array}$ & $\begin{array}{c}\text { Ethylene glycol } \\
\text { di-methyl ether } \\
\text { (DME) or } \\
\text { Dimethoxyethane } \\
\text { or Glyme }\end{array}$ & $\begin{array}{c}\text { Diethylene } \\
\text { glycol } \\
\text { dimethyl } \\
\text { ether } \\
\text { (Diglyme) }\end{array}$ \\
\hline Symbol & $\mathrm{C}_{2} \mathrm{H}_{6} \mathrm{O}$ & $\mathrm{C}_{10} \mathrm{H}_{22} \mathrm{O}_{4}$ & $\mathrm{C}_{4} \mathrm{H}_{10} \mathrm{O}_{2}$ & $\mathrm{C}_{6} \mathrm{H}_{14} \mathrm{O}_{3}$ \\
\hline $\begin{array}{c}\text { Molecular } \\
\text { weight } \\
\text { (g mol-1) }\end{array}$ & 46.07 & 206.3 & 90.14 & 134.174 \\
\hline $\begin{array}{c}\text { Density at } \\
20^{\circ} \mathrm{C}( \\
\text { kg.m-3) }\end{array}$ & 789 & 962 & 916 & 945 \\
\hline $\begin{array}{c}\text { Boiling } \\
\text { point }{ }^{\circ} \mathrm{C}\end{array}$ & 78.37 & 243 & 120 & 162 \\
\hline $\begin{array}{c}\text { Viscosity at } \\
20^{\circ} \mathrm{C} \\
\text { mpa.s }\end{array}$ & 1.2 & 5.5 & 1.7 & 24.5 \\
\hline $\begin{array}{c}\text { Flash Point } \\
{ }^{\circ} \mathrm{C}\end{array}$ & 13 & 121 & 31 & 67 \\
\hline $\begin{array}{c}\text { Oxygen } \\
\text { Content } \\
\% \text { wt }\end{array}$ & $34.78 \%$ & $31 \%$ & $35.56 \%$ & $35.8 \%$ \\
\hline $\begin{array}{c}\text { Lower } \\
\text { heating } \\
\text { value } \\
\text { MJ/Kg }\end{array}$ & 28.865 & 32.5 & 27.23 & 26 \\
\hline $\begin{array}{c}\text { Cetane } \\
\text { Number }\end{array}$ & 8 & 65 & 42 & 26 \\
\hline
\end{tabular}

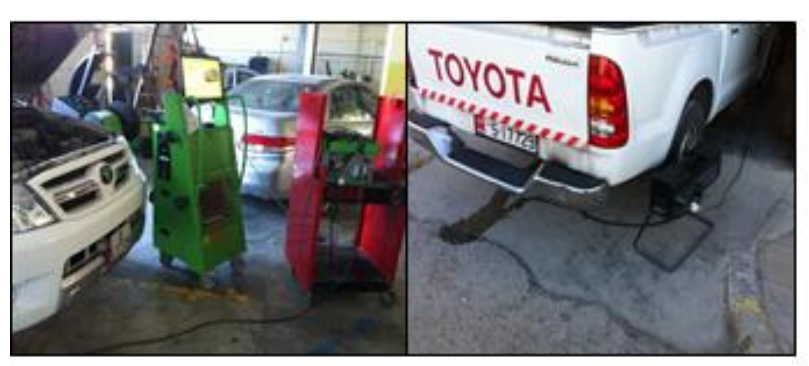

Fig. 1. Experimental setup of measuring PM emission

\subsection{Setup and Procedure}

A several experiments were carried out in Tafila Technical University automotive laboratories. The vehicle which was tested in these experiments was a 2006 Toyota Hilux Pickup with diesel engine capacity of $2494 \mathrm{cc}, 4$ cylinders inline DOHC 16 Valves, with its Controlled Area Network CAN-Bus was accessed through the On-Board Diagnostic OBD2 module. The experimental work is set according to the following steps; (i) Experiments were carried out at steady states at different engine speed with the same load; (ii) before beginning any operation test, the exhaust was cleaned in order to eliminate deposits and hydrocarbons of the previous test; (iii) the engine was warmed with the blend for at least 15 minutes to purge any of the remaining reference fuel from the engine fuelling system; (iv) The exhaust probe of smoke meter was inserted into exhaust pipe; (v) the particulate mass emission were continuously measured for five minutes and the average results 
presented; (vi) the steady state tests were repeated twice to ensure that the results are repeatable, and the relative standard deviations were less than 5\%; (vii) the same steps were repeated for oxygenated additives and volume ratios.

\section{Results and Discussion}

The variation of a particulate matter (PM) emission with engine speed for pure diesel and different blends of oxygenated diesel fuel in terms Ethanol, TGME, Glyme and Diglyme are depicted in figures 2, 3, 4 and 5 respectively. The average reduction of particulate matter emissions due to the introduction of oxygenated compounds is displayed in figure 6 . From these graphs, the following observations can be seen. The first observation is the higher the engine speed is, the lower PM emissions. It is due to the improved of the combustion efficiency resulted from an increase in turbulence effects with an increase in engine speed, which enhances the extent of complete combustion. These results was agreed to Kaplan et al. [17], Song et al [18]. Ulusoy et al. [19] and Lin et al [20]. The second observation is the PM emitted by all the oxygenated diesel blends is significantly lower than of the corresponding pure diesel fuel. There are several factors may contribute to the PM reduction which are mainly; (i) the oxygen in the blended fuel can stimulate the combustion during the stage of diffusion combustion [21]; so the higher oxygen content in oxygenated blend fuel, leads a combustion to be more complete, and further encourage the oxidation of soot; (ii) the decrease of aromatics compounds in the oxygenated diesel fuel. So, the PM generated by the dehydrogenation of polycyclic aromatic hydrocarbons is reduced [22]; (iii) increase of oxygen content is parallel to a decrease of carbon content in the oxygenated diesel fuels leading to the reduction of $\mathrm{C}-\mathrm{C}$ bonds in the blended fuel which are basically the source of PM; (iv) the temperature increase in diffusion combustion phase with the addition of oxygenated compound [23]; (v) finally, the oxygenated compounds had a dilution effect on the base fuel by replacing the highly sooting components of the base fuel with cleaner hydrocarbons [24]. The third observation is the increase of oxygenated compound percentage in the diesel blends, the PM emission decreases. This is because of better combustion of oxygenated diesel fuel. In addition, oxygenated fuel is essentially free of sulphur and aromatics. The fourth observation is the higher oxygen content in blend fuel the more PM reduction can be achieved. On the other side the higher density and viscosity of oxygenated blend fuel could affect the volatilization and atomization processes, and further decline combustion in chamber [25]. Although the blend diesel fuel with Diglyme is the richest oxygen content of all other blends, it is not the most PM reduction of all blend fuels due to higher density and viscosity. The fifth observation is the properties of ethanol, including low cetane number and poor solubility in diesel fuel especially in cold weather is major obstacles to use ethanol in diesel fuel without special additives [26]. The sixth observation is the mechanisms for the reduction the PM using oxygenate diesel fuel can be explained according to following steps [21,26-27]: (i) PM formation occurs in the fuel rich zone at high temperature and pressures, precisely within the core region of fuel drizzle; (ii) the oxygenates diesel fuel may effectively deliver oxygen to the pyrolysis zone and decomposition of the burning diesel drizzle leading to reduce PM production; (iii) the high radical concentrations especially $\mathrm{OH}$ reduces aromatic ring growth and soot particle initiation; (iv) finally, high radical concentrations as oxygenate addition reinforce carbon oxidation to $\mathrm{CO}$ and $\mathrm{CO} 2$, limiting carbon availability for PM formation. The seventh observation is the increase cetane number of oxygenated diesel fuel will advance in combustion, while the higher density and viscosity will advance of start of injection of biodiesel. The eighth observation is the lower boiling point of oxygenate diesel fuel enhances the probability of the lower PM as ethanol. The final observation is a maximum and minimum of PM reduction when the engine fueled by $15 \%$ by volume for ethanol and by $5 \%$ by volume for TGME respectively.

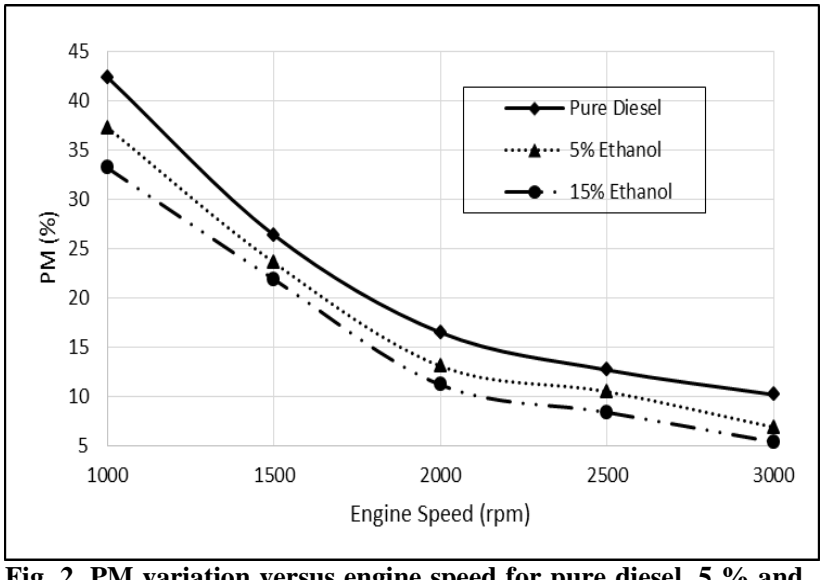

Fig. 2. PM variation versus engine speed for pure diesel, $5 \%$ and $15 \%$ ethanol addition

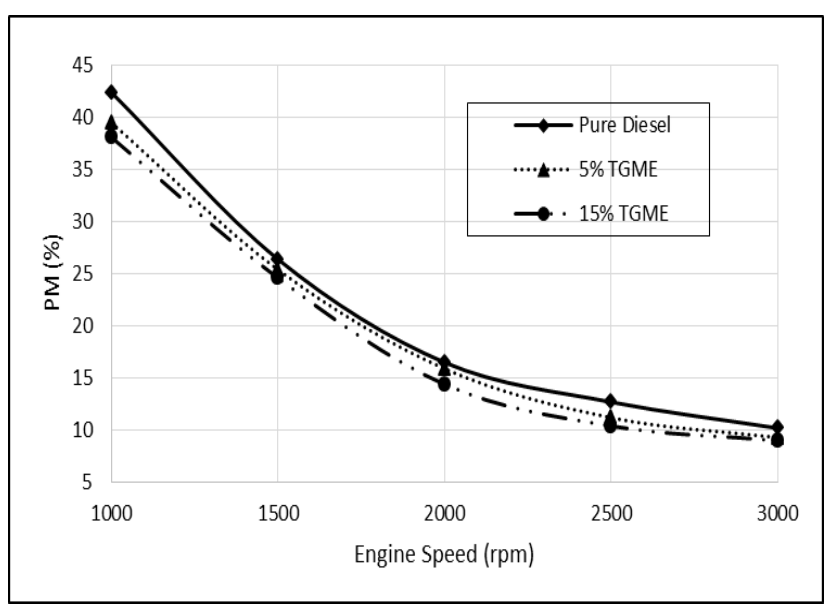

Fig. 3. PM variation versus engine speed for pure diesel, $5 \%$ and $15 \%$ TGME addition

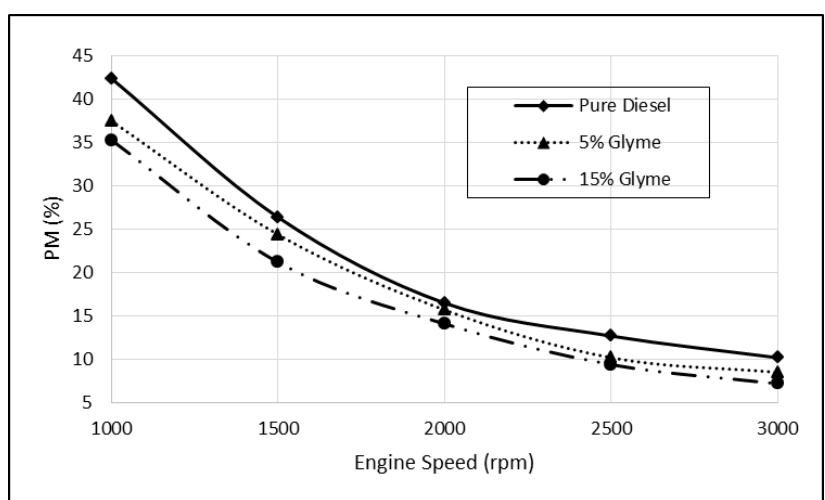

Fig. 4. PM variation versus engine speed for pure diesel, $5 \%$ and $15 \%$ Glyme addition. 


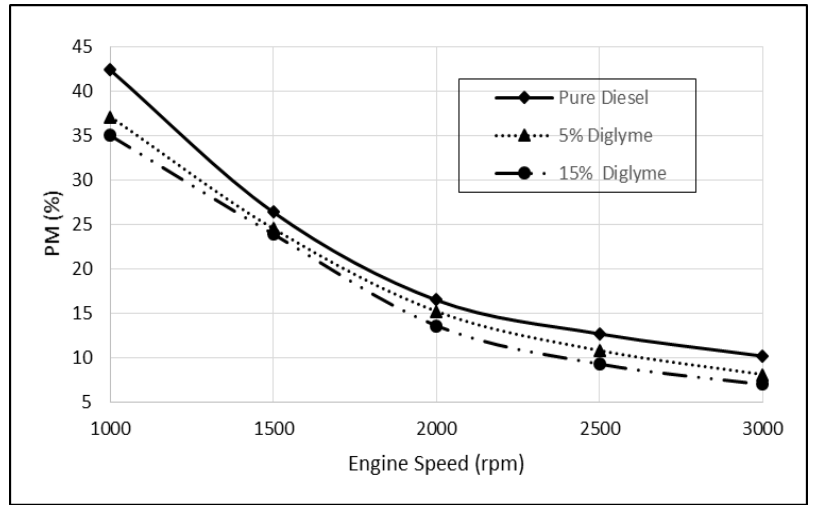

Fig. 5. PM variation versus engine speed for pure diesel, $5 \%$ and $15 \%$ Diglyme addition

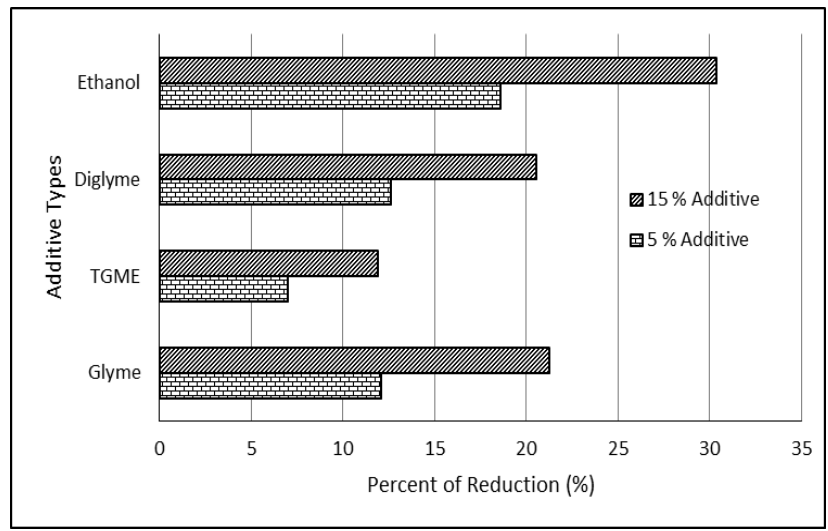

Fig. 6. Average reduction of PM emissions for different oxygenated additives

\section{Conclusion}

This manuscript describes an experimental investigation of particulate emissions from a diesel engine fueled with various oxygenated compounds. Two blended fuels containing $5 \%$ and $15 \%$ by volume for each oxygenated additives was prepared. The main results are summarized as follows:

- $\quad$ The higher the engine speed is, the lower PM emissions. It is due to the improved combustion efficiency resulted from an increase in turbulence.

Ethanol has been found to be promising fuel oxygenate additive due to high oxygen content, lower density, boiling point and viscosity. On the side the low cetane number and poor solubility in diesel fuel especially in cold weather is major obstacles to use ethanol in diesel fuel without special additives.

The PM emissions reduction were largely dependent on the oxygen content of the fuel.

- A maximum and minimum of PM reduction when the engine fueled by $15 \%$ by volume for ethanol and by $5 \%$ by volume for TGME respectively.

\section{References}

[1] W. Ying, Z. Longbao, W. Hewu, Diesel emission improvements by the use of oxygenated DME/diesel blend fuels, Atmospheric Environment 40 (13) (2006): 2313-2320. doi: 10.1016/j.atmosenv.2005.12.016

[2] Car Emissions \& Euro 5 emission standards, Available: http://www.nextgreencar.com/caremissions.php, last cited: February 16, 2014.

[3] P. Frijters, R. Baert, Oxygenated fuels for clean heavyduty diesel engines, Int. J. Vehicle Design $41(1-4)$ (2006): 242-255. doi: 10.1504/IJVD.2006.009671

[4] A. Patil, S.G. Taji, Need of composite additives for diesel fuel: A review, International Journal of Engineering Research \& Technology 2 (11) (2013): 2652-2656.

[5] T.C. Zannis, D.T. Hountalas, DI diesel engine performance and emissions from the oxygen enrichment of fuels with various aromatic content, Energy Fuel 18 (3) (2004): 659-66 . doi: 10.1021/ef0301598

[6] N.M. Ribeiro, et al., The role of additives for diesel and diesel blended (ethanol or biodiesel) fuels: A review, Energy Fuels 21 (4) (2007): 2433-2445. doi: 10.1021/ef070060r

[7] R. Mccormick, J. Ross, M. Graboski, Effect of several oxygenates on regulated emissions from heavy-duty diesel engines, Environ. Sci. Technol. 31 (1997): 1144-1150. doi: $10.1021 /$ es 9606438

[8] X. Shi, Y. Yu, H. He, S. Shuai, J. Wang, R. Li, Emission characteristics using methyl soyate-ethanoldiesel fuel blends on a diesel engine, Fuel 84 (12-13) (2005): 1543-1549. doi: 10.1016/j.fuel.2005.03.001

[9] J.E. Schaus, P. McPartlin, R.L. Cole, R.B. Poola, R. Sekar, Effect of ethanol fuel additive on diesel emissions. Report by Argonne National Laboratory for Illinois Department of Commerce and Community Affairs and US Department of Energy. (2000).

[10] B. He, S. Shuaia, J. Wang, H. He, The effect of ethanol blended diesel fuels on emissions from a diesel engine, Atmospheric Environment 37 (35) (2003): 4965-4971. doi: 10.1016/j.atmosenv.2003.08.029

[11] P. Baskar, K. Nanthagopal, T. Elango, The effect of two oxygenates on diesel engine emissions, Journal of Engineering and Applied Sciences 6 (3) (2011): 55-60.

[12] C. Lin, J. Huang, An oxygenated additive for improving the performance and emission characteristics of marine engines, Ocean Engineering 30 (13) (2003): 1699-1715. doi: 10.1016/S0029-8018(02)00149-X

[13] K.I. Burshaid, M.A. Hamdan, The reduction of soot formation from fuels using oxygenates additives, Energy Conversion and Management 65 (2013): 751-754. doi: 10.1016/j.enconman.2012.02.033

[14] Z.M. Hasib, K.A. Rahman, Performance characteristics analysis of small diesel engines fueled with different blends of mustard oil bio-diesel, Int. J. of Thermal \& Environmental Engineering 6 (1) (2013): 43-48. doi: 10.5383/ijtee.06.01.007 
[15] A.R. Patil, S.G. Taji, Effect of oxygenated fuel additive on diesel engine performance and emission: A review. IOSR Journal of Mechanical and Civil Engineering (IOSR-JMCE). (2013): 30-35.

[16] M. Hijazi, Experimental study to reduce the emission of particulate matter during the combustion of diesel fuel, Master Dissertation. Mechanical Engineering Department, University of Jordan. (2006).

[17] C. Kaplan, R. Arslan, A. Surmen, Performance characteristics of sunflower methyl esters as biodiesel, Energ Source Part A. 28 (8) (2006): 751-755. doi: $10.1080 / 009083190523415$

[18] J.T. Song, C.H. Zhang, An experimental study on the performance and exhaust emissions of a diesel engine fuelled with soybean oil methyl ester, Proceedings of the Institution of Mechanical Engineers, Part D: Journal of Automobile Engineering 222 (12) (2008): 2487-2496. doi: 10.1243/09544070JAUTO932

[19] Y. Ulusoy, R. Arslan, C. Kaplan, Emission characteristics of sunflower oil methyl ester, Energ Source Part A. 31 (2009): 906-910. doi: $10.1080 / 15567030802087528$

[20] C.Y. Lin, R.J. Li, Engine performance and emission characteristics of marine fish-oil biodiesel produced from the discarded parts of marine fish, Fuel Process Technol. $90 \quad(7-8) \quad$ (2009) 883-888. doi: 10.1016/j.fuproc.2009.04.009

[21] Y. Di, C. Cheung, Z. Huang, Experimental investigation of particulate emissions from a diesel engine fueled with ultralow-sulfur diesel fuel blended with Diglyme,
Atmospheric Environment 44 (1) (2010): 55-63. doi: 10.1016/j.atmosenv.2009.09.039

[22] Y. Di, C. Cheung, Z. Huang, Comparison of the effect of biodiesel-diesel and ethanol-diesel on the particulate emissions of a direct injection diesel engine, Aerosol Science and Technology 43 (5) (2009): 455-465. doi: $10.1080 / 02786820902718078$

[23] Y. Ren, Z. Huang, H. Miao, D. Jiang, K. Zeng, B. Liu, $\mathrm{X}$. Wang, Effect of the addition of diglyme in diesel fuel on combustion and emissions in a compression-ignition engine. Energy \& Fuels 21 (5) (2007): 2573-2583. doi: 10.1021/ef070140v

[24] P. Pepiot-Desjardins, H. Pitsch, R. Malhotra, S.R. Kirby, A.L. Boehman, Structural group analysis for Soot reduction tendency of oxygenated fuels. Combustion and Flame $\quad 154$ (2008): 191-205. doi: 10.1016/j.combustflame.2008.03.017

[25] M. Lapuerta, O. Armas, J. Rodriguez-Fernandez, Effect of biodiesel fuels on diesel engine emissions, Progress in Energy and Combustion Science 34 (2) (2008): 198-223. doi: 10.1016/j.pecs.2007.07.001

[26] X. Shi, X. Pang, Y. Mu, H. He, S. Shuai, J. Wang, H. Chen, R. Li, Emission reduction potential of using ethanol - biodiesel - diesel fuel blend on a heavy - duty diesel engine. Atmospheric Environment. 40 (14) (2006): 2567-2574. doi: 10.1016/j.atmosenv.2005.12.026

[27] A.S. Cheng, R.W. Dibble, B.A. Buchholz, The effect of oxygenates on diesel engine particulate matter, SAE Technical Paper No. 2002-01-1705 (2002). 